\title{
ФОРМИРОВАНИЕ У СТУДЕНЧЕСКОЙ МОЛОДЕЖИ СПЕЦИАЛЬНЫХ КОМПЕТЕНЦИЙ ВОЛОНТЕРСКОЙ ДЕЯТЕЛЬНОСТИ
}

\section{FORMATION OF SPECIAL COMPETENCIES OF VOLUNTEER ACTIVITIES \\ IN THE FIELD OF SOCIAL INCLUSION AMONG STUDENTS}

\section{O. Lipunova}

Summary: The results of a study on the implementation of an additional professional program for the preparation of student youth for volunteering with children with disabilities "Formation of special competencies of volunteer activities in the field of social inclusion among students" are presented. Based on the analysis of the problem of organizing student volunteer activities in the practice of inclusive education, we investigated the formation of volunteers' theoretical knowledge and practical skills to accompany children with disabilities, the content of the program is aimed at systematizing and deepening.

Keywords: volunteer, volunteering, children with disabilities, inclusion, organizing volunteer activities with children with disabilities.

\author{
Липунова Ольга Владимировна \\ ФГБОУ ВО «Амурский гуманитарно-педагогический \\ государственный университет» \\ (2. Комсомольск-на-Амуре) \\ belousowa29@mail.ru
}

Аннотация: Изложены результаты исследования по реализации дополнительной профессиональной программы по подготовке студенческой молодежи к волонтерской деятельности с детьми с ограниченными возможностями здоровья «Формирование у студенческой молодежи специальных компетенций волонтерской деятельности в области социальной инклюзии». На основе анализа проблемы организации студенческой волонтерской деятельности в практике инклюзивного образования исследована сформированность у волонтеров теоретических знаний и практических умений по сопровождению детей с ограниченными возможностями здоровья, на систематизацию и углубление у которых направлено содержание программы.

Ключевые слова: волонтерство, дети с ограниченными возможностями здоровья, инклюзия, организации волонтерской деятельности с детьми с ограниченными возможностями здоровья

го-педагогическому сопровождению детей с ограниченными возможностями здоровья [4;6].

Помощь детям с ограниченными возможностями здоровья рассматривают в качестве перспективного и активно реализуемого на сегодняшний день направления волонтерской деятельности [7; 12].

Анализ современных исследований позволяют говорить о том, что основную массу волонтеров составляет молодежь, в том числе - студенческая. Соответственно, важнейшим ресурсом волонтерского движения, по мнению, Н.Ю. Прияткиной, являются студенты [7].

Современные исследователи отмечают, что специфические особенности коммуникации детей с ограниченными возможностями здоровья, их особые образовательные потребности требуют специальной подготовки волонтеров для эффективной организации работы по оказанию помощи таким детям. Соответственно, уровень развития и успешность студенческого волонтерства, его роль и вклад в инклюзивное образование зависят от качества подготовки к этой деятельности участников волонтерского движения [6; 10; 11; 12].

И.А. Степанова выделяет следующие этапы обучения 
волонтеров:

1 этап - теоретический, включающий в себя теоретическую подготовку в рамках общепрофессиональных, специальных дисциплин и специализации, и проектнотренингового компонента (программа подготовки волонтеров, практические семинары и тренинги, проектирования возможных проблемных ситуаций и способов их разрешения).

2 этап - практический, включающий волонтерскую практику, практику в социальных учреждениях, работу в волонтерских отрядах и группах, разработку и реализацию волонтерских акций [9].

На сегодняшний день подготовка студенческой молодежи к организации волонтерской деятельности с детьми с ограниченными возможностями здоровья рассматривается как одно из приоритетных направлений профессионализации молодых специалистов, так как участие в добровольчестве способствует развитию рефлексии, стимулирует самореализацию, личностное совершенствование [10].

Целью настоящего исследования явилась разработка и реализация дополнительной профессиональной программы подготовки волонтеров к работе с детьми с ограниченными возможностями здоровья «Формирование у студенческой молодежи специальных компетенций волонтерской деятельности в области социальной инклюзии».

Задачи исследования:

- разработка дополнительной профессиональной программы обучения волонтеров работе с детьми с ограниченными возможностями здоровья;

- организация обучения привлеченных добровольцев (волонтеров) технологиям работы с детьми с ограниченными возможностями здоровья.

Разработанная программа преследовала целью обучения систематизацию и углубление у волонтеров теоретических знаний и практических умений по сопровождению детей с ограниченными возможностями здоровья.

Процесс разработки программы включал следующие этапы:

- определение цели, задач и содержания обучения;

- моделирование программы обучения (содержание разделов, формы и методы обучения, количество часов);

- организация процесса обучения волонтеров (определение времени, места, технического и информационного обеспечения;

- анализ результатов обучения с использованием фонда оценочных средств (в процессе реализации программы, после изучения каждого раздела, после завершения всего курса обучения).

Оценка результатов обучения позволяет оценить готовность волонтеров к предстоящей работе, а также важна для планирования дальнейшего обучения волонтеров и внесения необходимых корректив в программу.

Цель реализации программы - овладение волонтерами необходимыми профессиональными и личностными компетенциями: психолого-педагогическими технологиями и методиками работы с детьми с ограниченными возможностями здоровья; навыками межличностного взаимодействия с ограниченными возможностями здоровья, навыками эффективного общения с «особыми» детьми.

\section{Задачи программы:}

- обеспечить слушателей теоретической подготовкой по вопросам межличностного взаимодействия с детьми с ограниченными возможностями здоровья, навыками эффективного общения с «особыми» детьми;

- сформировать представление о психолого-педагогических технологиях и методиках работы с детьми с ограниченными возможностями здоровья.

Планируемые результаты освоения программы представленная профессиональная образовательная программа направлена на формирование навыков организации взаимодействия с детьми с ОВ3.

Трудоемкость и срок освоения программы: трудоемкость - 144 часа; срок обучения - 2 месяца.

Программа реализуется в очной форме (сетевой форме с использованием дистанционных технологий).

Занятия в рамках программы проводили в свободное от учебного процесса время, на добровольной основе, с использованием группового метода обучения. Использовали комбинации различных методов обучения: презентации, лекции, работа в группах, ролевые игры, дискуссии, практические фильмы и занятия, консультации специалистов.

В процессе реализации программы предпочтение отдавали тем методам, которые основаны на примерах из практики, стимулировали активное участие волонтеров в обучении, обеспечивали обратную связь. Также, в рамках запланированного времени, предоставляли возможность участникам для обмена мнениями.

В процессе обучения особое внимание уделяли предоставлению волонтерам необходимой информации 
и отработке, и закреплению приобретаемых знаний и навыков, в том числе и для достижения необходимой степени подготовленности, уверенности в своих силах, оптимального уровня понимания волонтерами своих функций.

С целью оценки результатов освоения обучающимися дополнительной профессиональной программы проводился безоценочный текущий контроль успеваемости, предполагающий качественную характеристику (оценку) сформированности у обучающихся соответствующих компетенций и устные рекомендации обучающимся волонтерам по повышению успешности освоения программы. Текущий контроль осуществлялся с использованием фондов оценочных средств. Проведение итоговой аттестации по дополнительной профессиональной программе не предусмотрено.

Программа реализовывалась в период октябрь-ноябрь 2021 года. По указанной программе прошли обучение 62 студента-волонтера Комсомольского-на- Амуре филиала краевого государственного бюджетного образовательного учреждения среднего профессионального образования «Хабаровский государственный медицинский колледж».

Обучение проводилось в рамках реализации гранта.

Кадровое обеспечение программы: реализацию программы осуществляли преподаватели кафедры дошкольной и коррекционной педагогики и психологии ФГЮОУ ВО «Амурский гуманитарно-педагогический государственный университет», имеющие знания и опыт работы в области оказания социальных услуг инвалидам, детям-инвалидам, детям с ограниченными возможностями здоровья и членам их семей.

Представленная программа дополнительного образования «Формирование у студенческой молодежи специальных компетенций волонтерской деятельности в области социальной инклюзии» разработана с учетом положений Федерального закона от 29 декабря 2012 г. № 273-Ф3 «Об образовании в Российской Федерации», Порядка организации и осуществления образовательной деятельности по дополнительным общеобразовательным программам, утвержденного приказом Министерства просвещения РФ от 9 ноября 2018 года №196,; Порядка применения организациями, осуществляющими образовательную деятельность, электронного обучения, дистанционных образовательных технологий при реализации образовательных программ, утвержденного приказом Министерства образования и науки РФ от 23 августа 2017 года №816; положения о дополнительной профессиональной образовательной программе ФГБОУ ВО «АмГПГУ» (РДО ВУД 365-2.54-2016).
Категория слушателей - привлеченные добровольцы (волонтеры), осуществляющие помощь детям с ограниченными возможностями здоровья.

Форма обучения - очно-заочная, с использованием дистанционных образовательных технологий.

По окончании обучения в полном объеме обучающийся получает сертификат о прохождении обучения по установленному образцу.

Реализацию программы осуществляли в несколько этапов.

На первом этапе реализации программы обучения волонтеров прошла встреча с волонтерами, на которой обсуждалось содержание предстоящего обучения, программа обучения, ожидания волонтеров от обучения.

Также на данном этапе нами, с использованием специально разработанной анкеты, был проведен анализ сформированности представлений у волонтеров: о детях с ограниченными возможностями здоровья; о психолого-педагогических технологиях и методиках работы с детьми с ограниченными возможностями здоровья; особенностях межличностного взаимодействия с детьми с ограниченными возможностями здоровья.

Согласно анализу полученных результатов, исследуемые волонтеры имеют представление о детях с ограниченными возможностями здоровья, при этом исследуемые волонтеры нуждаются в дополнительной подготовке для оптимизации межличностного взаимодействия с детьми с ограниченными возможностями здоровья при их сопровождении в рамках мероприятий различного характера. Также полученные результаты свидетельствуют о том, что исследуемые волонтеры не в полной мере осведомлены о закономерностях развития, характерных для детей с ограниченными возможностями здоровья; не владеют в достаточном объеме знаниями о технологиях сопровождения детей с ограниченными возможностями здоровья. Большинство исследуемых волонтеров продемонстрировали несформированность навыков социальной коммуникации с детьми с ограниченными возможностями здоровья.

Второй этап реализации программы обучения волонтеров заключался в формировании у волонтеров знаний и навыков, необходимых для начала практической деятельности: собственно обучение; оценку результатов обучения (насколько волонтер уверенно применяет полученные знания и навыки на практике).

На третьем этапе реализации программы обучения волонтеров было проведено повторное анкетирование 
с целью анализа динамики знаний и представлений волонтеров о детях с ограниченными возможностями здоровья. Сравнительный анализ результатов первичного и повторного анкетирования свидетельствует о сформированности представлений о детях с ограниченными возможностями здоровья, о формах организации специального обучения и воспитания детей с ограниченными возможностями здоровья, о содержании, формах и методах работы с детьми с ограниченными возможностями здоровья, об особенностях коммуникации с детьми с ограниченными возможностями здоровья.

Для подтверждения статистической значимости выявленных различий в исследуемых показателях у волонтеров мы использовали метод статистического анализа - коэффициент $\varphi^{*}$ угловое преобразование Фишера.

Полученные результаты свидетельствуют о том, что наиболее значимыми являются изменения в следующих показателях: понимание и учет закономерностей психического развития детей с ограниченными возможностями здоровья, сформированность навыков общения и взаимодействия с детьми с ограниченными возможностями здоровья. Различия по указанным показателям являются, согласно анализу результатов исследования,

\section{статистически значимыми.}

Таким образом, в процессе обучения по дополнительной профессиональной программе волонтерами приобретены практические навыки формирования инклюзивного пространства для реализации специализированных программ, направленных на социализацию, профориентацию, творческую реализацию детей с ограниченными возможностями здоровья.

Согласно анализу результатов проведенного исследования, представленная дополнительная профессиональная программа может быть использована для формирования у студенческой молодежи готовности к оптимизации взаимодействия с детьми с ограниченными возможностями здоровья на основе сформированных знаний о закономерностях психического развития отдельных категорий детей с ОВ3, о специфике их психолого-педагогического сопровождения. Реализация представленной дополнительной профессиональной программы может быть использована для формирования у волонтеров из числа студенческой молодежи готовности активно использовать имеющиеся знания для создания условий успешной социализации детей с ограниченными возможностями здоровья.

\section{ЛИТЕРАТУРА}

1. Барябина Е.Н. Теория и практика волонтерского движения. Методическое пособие Е.Н. Барябина, П.В Романов, И.В Шатылко. - Саратов: 000 Бонапарт ПС, 2003. - 205 c.1.

2. Левдер И.А. Добровольческое движение как одна из форм социального обслуживания / И.А. Левдер // Социальная работа. - 2006. - №2. - С. 35 - 39.

3. Методические рекомендации по развитию сети волонтерских центров инклюзивного добровольчества / ред. - сост. Л.И. Быстрова, Л.В. Галиханова, Е.В. Крутицкая. - Москва: Издательство РГСУ, 2018. - 102 с.

4. Методы психолого-педагогического и медико-социального сопровождения детей-инвалидов и детей с ограниченными возможностями здоровья: методические материалы / [Е.А. Шмелева, С.А. Лебедева, Л.Д. Мальцева, П.А. Кисляков, О.А. Силаева, Н.Ю. Прияткина, Н.А. Лаврух, А.А. Малгина]; под ред. Е.А. Шмелевой, М.А. Правдова. — Шуя: Изд-во Шуйского филиала ИвГУ, 2016. - 72 с.

5. Подготовка волонтеров в классическом университете / А.В. Бабичева, Л.В. Вандышева, К.О. Вартанян [и др.]; под общ. ред. Л.В. Вандышевой. - Самара: Самарский университет, 2012. - 168 с.

6. Подготовка волонтеров к работе с инвалидами: учебно-методическое пособие / М.А. Зыскина, Е.А. Романова. - Екатеринбург: Издательство УмЦ УПИ, 2011. - 98 с.

7. Прияткина Н.Ю. Подготовка волонтеров к деятельности с детьми с ограниченными возможностями здоровья // Современные проблемы науки и образования. - 2016. - № 4.; URL: https://science-education.ru/ru/article/view?id=25022 (дата обращения: 27.10.2021).

8. Сикорская Л.Е. Добровольческая деятельность как школа нравственного воспитания молодежи /Л.Е. Сикорская // Вестник Вятского государственного гуманитарного университета. - 2009. - № 3. - С.98-103.

9. Степанова И.А. Формирование мобильности будущих специалистов социальной сферы в волонтерской деятельности. Автореф. дис. ... канд. пед. наук. - M., 2010. -25 c.

10. Формирование личности студентов в процессе волонтерской деятельности. / А.Б. Ооржак // Журнал: Новая наука: опыт, традиции, инновации. № 1-2 (59).

11. Шагурова А.А. Социально-психологическая готовность молодежи к волонтерской деятельности: автореф. дис. ... канд. психолог. наук. - М., 2013. - 25 с.

12. Шевырева Е.Г., Игнатенко А.Г. Психолого-педагогическое сопровождение подготовки волонтеров к работе с детьми с ограниченными возможностями здоровья // Евразийский Союз Ученых (Психологические науки). - 2014. - № 6. - С. 156-157. 